AGRICULTURE AND BIOLOGY JOURNAL OF NORTH AMERICA

ISSN Print: 2151-7517, ISSN Online: 2151-7525, doi:10.5251/abjna.2011.2.3.471.475

(C) 2011, ScienceHu, http://www.scihub.org/ABJNA

\title{
Effect of distance from Jatropha curcas hedgerow on growth and yield of Zea mays
}

\author{
Abugre $S .{ }^{1}$ C. Oti-Boateng ${ }^{2}$ and A, Adu-Gyamfi ${ }^{2}$ \\ ${ }^{1}$ Faculty of Forest Resources Technology, KNUST, Sunyani, Ghana. \\ ${ }^{2}$ Faculty of Renewable Natural Resources, KNUST, Sunyani, Ghana. \\ ${ }^{1}$ Corresponding author's Phone: +233209500070, Email: simabu2001@yahoo.com
}

\begin{abstract}
The experiment was done to find out the effect of hedgerow distance on the growth and yield of maize. The Randomized Complete Block Design (RCBD) with 3 replications was used to lay out the experiment. Three hedgerow distances $0 \mathrm{~m}$ (no hedgerow), $1 \mathrm{~m}$ and $2 \mathrm{~m}$ were the treatments used. The results showed no significant effect of Jatropha curcas hedgerow distance on growth and yield of maize in the first year. In the second year, significant differences were realized in plant height, diameter, stover weight, grain weight, weight of cob and weight of seed/cob. The closest distance from hedgerow $(1 \mathrm{~m})$ gave lowest plant height $(2.30 \mathrm{~m})$, diameter $(14.17 \mathrm{~mm})$ and stover weight (5.42 tons/ha). Grain weight (1.98 tons/ha), weight of cob (205.7 g), weight of seed/cob (100.2 g) was lowest at $1 \mathrm{~m}$. It can be concluded that closer spacing at 2 years would have an effect on growth and yield of maize.
\end{abstract}

Keywords: Jatropha curcas, Maize, growth, yield

\section{INTRODUCTION}

The exploitation of bio-energy sources of fuel has recently been given much prominence by the scientific community and commercial entrepreneurs as a way to solve the energy crisis. Bio-diesel is the most valuable form of renewable energy that can be used directly in any existing unmodified diesel engine (Shekhawat et al., 2009). It is an alternative fuel that can be used in diesel engines and provides power similar to conventional diesel fuel. Biofuel can help reduce the countries dependence on foreign oil imports. Recent environmental and economic concerns (Kyoto protocol) have prompted resurgence in the use of biodiesel throughout the world. In 1991, the European Community, (EC) proposed a 90\% tax reduction for the use of biofuels, including biodiesel (Shekhawat et al., 2009). Biofuel create new markets for agricultural products and stimulate rural development because biofuels are generated from crops, they hold enormous potential for farmers.

The long term challenge is the ability to supply feedstock to keep up with growing demand. The supply of feed stock from maize, soya beans will be limited by competition from other uses and land constraints. As such the key to the future of biofuels is finding inexpensive feed stocks that can be grown by farmers. Jatropha curcas proves to be one of the many plants that hold great promise as a biofuel crop. Jatropha curcas is more recently cultivated a bio-diesel plant. Soybean and Rapseed have a relatively low oil yield compared with Jatropha curcas. A yield of $375 \mathrm{~kg} / \mathrm{ha}$ (280 gallons/acre) is reported for soybean in the United States. In Europe, yield for rape seeds are said to be $1000 \mathrm{~kg} / \mathrm{ha}$ (740 gallons per acre) whilst in India, Jatropha curcas is reported to have yield of $3000 \mathrm{~kg} / \mathrm{ha}(2226$ gallons/acre). (Shekhawat et al, 2009)

The world's population has grown from 1980 to over 6 billion in 2000 (US Census Bureau, 2002) and finite availability of fertile land makes meeting energy needs for this growing population difficult. Ghana had a population of about 12.4 million in 1984 . This figure increased to 18.8 million in 2000 with an intercensal growth rate of $2.6 \%$. The increase in population has caused a corresponding rise in food and fuel consumption, straining the earth's natural resources (FAO, 2003). In developing countries, the pressure on natural resources is more acute because nearly $70 \%$ are subsistence-based and live in rural communities. Heavily reliant on natural resources for food and energy, people by their basic instinct to survive and derive their diet from their surroundings (Abalu and Hassan, 1999; Scoones, 1998). There is growing recognition of the necessity to understand different people's relation with their environment and to incorporate this knowledge into decision-making and planning (Twyman, 2001). 
Promoting rural development and faster agricultural growth by diversifying agricultural exports and improving agricultural productivity is critical both for accelerating growth and promoting a pattern of growth more conducive to reducing poverty (OCAR). The total land area of Ghana is about 23.8 million hectares of which $35 \%$ is cultivated. Ghana's agriculture is predominantly small holder, traditional and rain-fed. Agricultural production is undertaken by about 2 million, predominantly small holder subsistence farmers who account for about $80 \%$ of food in the country. The mean farm size is less than 1.2 hectares with a few exceeding two hectares (OCAR, 2002). Small and medium sized farms of up to 10 hectares account for $95 \%$ of all cultivated land. This shows the importance of small holders in agricultural production (World Bank, 1994). Agricultural land availability has reduced from 1.56 ha in 1970 to 1.11 ha in 1984 to 0.74 in 2000. This shows that there has been pressure on the country's land resources over the past three decades. Increasing pressure on limited land resources is a problem being faced in rural Ghana. Subsistence farmers in these areas practice traditional bush fallow, clearing and burning bush at short intervals to grow annual food crops. The problem of population growth coupled with economic pressure has resulted in a high rate of deforestation of the country natural forests. The traditional farming system is shifting cultivation and its productivity depends largely on the fertility of the soil, which is usually maintained by long fallow periods. Fallow periods have however been reported to have steadily reduced over the years. Communal ownership is the main feature of land tenure in most of Ghana. Such land is controlled by lineage or clan based land-owning groups and allocated to individuals or household on a usufruct basis. Those without usufruct rights may also gain access to land through customary share cropping agreements. Under this traditional system both men and women can access land as long as they are recognized members of the local communities (OCAR, 2002)

Agroforestry is credited with improving the utilization of space by improving recycling of nutrients and organic matter. This translates into improved soil chemical, physical and biological characteristics with a reduction in the use of chemical fertilizers and improved infiltration of water. There is higher aggregate biomass production from an agroforestry mixture than from monoculture. Microclimate extremes are reduced as is soil erosion. Agroforestry thus provides a more favourable environment for sustained cropping, the creation of habitat diversity and provides a more continuous flow of more products over time (Cameron et al., 1991). A promising agroforestry technology for the humid and sub-humid tropics, which has been developed during the past decades, is alley cropping or hedgerow intercropping.

Alley cropping also known as hedgerow intercropping has been the subject of intensive research at the International Institute for Tropical Agriculture (IITA) in Nigeria (Kang et al., 1981a; Kang et al., 1981b). The concept of alley cropping was formalized at IITA where the term was defined as the growing of crops, usually food crops, in alleys formed by trees or woody shrubs that are established mainly to hasten soil fertility restoration and enhance productivity (Wilson and Kang, 1981). It entails growing food crops between hedgerows of planted shrubs and trees, preferable leguminous species. It is a management-intensive system that can lead to increased crop yields and productivity of the land.

Maize (Zea mays L.) belongs to the family Poaceae (Gramineae) and the tribe maydeae. Maize is an annual short days, cross pollinated crop. Based on area and production, maize is one of the most important cereal crops in Ghana. Maize plant have an erect stem which bear alternate leaves tassel at the top and auxiliary female inflorescence known as ear in the middle. The yield in Ghana is low compared to other maize producing countries. There is concern that the use of land for the cultivation of bio-fuels could further jeopardize our self- sufficiency in maize production. Maize is one of the most important cereal crops of Ghana. Increasing grain yield per unit area and increasing the corn cultivable area are recognized as a better solution to solve the gap between consumption and production. In the midst of limited land for the cultivation of both maize and Jatropha curcas, it is surmised that the integration of these in an alley cropping could help provide the appropriate output from these plants. The study was therefore designed to determine the appropriate spacing from hedgerow in order to minimize competition with maize cv. obatampa in a Jatropha curcas hedgerow intercropping system.

\section{MATERIALS AND METHOD}

Study Area : The experiment was laid at Ayakumaso, Suunyani, Ghana. It lies at latitude $7^{\circ} 55^{\prime} \mathrm{N}$ and $7^{\circ} 35^{\prime} \mathrm{N}$ and longitude $2^{\circ} 00^{\prime} \mathrm{W}$ and $2^{\circ} 30 \mathrm{~W}$. It is located 229 and 376 meters above sea level (SMA, 1998). 
The area has a tropical climate, with high temperatures averaging $23.9^{\circ} \mathrm{C}\left(75^{\circ} \mathrm{F}\right)$. Its mean monthly temperature varies between $23^{\circ} \mathrm{C}$ and $33^{\circ} \mathrm{C}$ with the lowest in august and highest in March or April. The study area has a double maxima rainfall pattern. Rainfall ranges, from an average of 1000 $\mathrm{mm}$ in the northern parts to $1400 \mathrm{~mm}$ in the southern parts. The major rainy season occurs from April to end of July whilst September to October is the minor wet season.

The vegetation type is the moist semi-deciduous forest. The soils are of ferric acrisols (FAO Classification).

Design of Experiment: The experiment was laid using the Randomized Complete Block Design (RCBD). Three hedgerow spacing treatments of $0 \mathrm{~m}$ (No hedgerow), $1 \mathrm{~m}$ and $2 \mathrm{~m}$ of Jatropha curcas was used with 3 replications. The alleys of Jatropha curcas were established on the $1^{\text {st }}$ of May, 2008. The test crop used was Maize (Zea mays, var Obatampa). The test crop was sown at a spacing of $100 \mathrm{~cm} \times 40 \mathrm{~cm}$ at a population of 25,000 plants $\mathrm{ha}^{-1}$. The planting date for the maize was $21^{\text {st }}$ July, 2008 and repeated on the $25^{\text {th }}$ July, 2009.

$50 \mathrm{~kg}$ of 15-15-15 fertilizer was applied as a starter fertilizer at 7 days after sowing at $5 \mathrm{~cm}$ from the hills. Five bags of $50 \mathrm{~kg}$ were applied per hectare. At five weeks after sowing, maize was top dressed with 2.5 bags of $50 \mathrm{~kg}$ urea per hectare. Using the No-till technology in land preparation, Round up was used for the initial weed control. $180 \mathrm{ml}$ of round up was put into 15 litres of water in a knapsack sprayer. Hand weeding was done twice ( 3 and 5 weeks after planting) before the harvest.

All data recorded were analyzed using the GENSTAT package. The Analysis of Variance (ANOVA) was generated to determine if there were any significant differences between the treatments. The Fishers Least Significant Difference (LSD) was then used to separate the means between the treatments at $5 \%$ probability level.

\section{RESULTS}

Effect of distance from Jatropha curcas hedgerow on growth of maize: Distance from hedgerow was not significant $(P<0.05)$ for height, diameter, number of leaves, number of nodes and stover weight in the first year (Table 1 and 3). In the second year, significant differences were observed for plant height, diameter and Stover weight (Table 1 and 3). In all cases, the distance of $1 \mathrm{~m}$ from hedgerow gave the lowest growth of maize. Maize had the highest height of $2.45 \mathrm{~m}$, diameter of 19.48 and stover weight of 7.83 tons $\mathrm{ha}^{-1}$ at the control treatment. These results did not differ significantly from $2 \mathrm{~m}$ distance from hedgerow (Table 1 and 3 ). The lowest results were obtained at $1 \mathrm{~m}$ from hedgerow.

Table 1: Effect of distance from Jatropha curcas hedgerow on growth of Maize.

\begin{tabular}{|l|c|c|c|c|c|c|c|c|}
\hline $\begin{array}{l}\text { Treatments } \\
\text { (Distance from } \\
\text { Hedgerow) }\end{array}$ & \multicolumn{3}{|c|}{ Height (m) } & \multicolumn{2}{c|}{$\begin{array}{c}\text { Diameter at 1 node } \\
(\mathrm{mm})\end{array}$} & \multicolumn{2}{c|}{$\begin{array}{c}\text { Number of leaves } \\
\text { Number of nodes per } \\
\text { plant }\end{array}$} \\
\cline { 2 - 9 } & 2008 & 2009 & 2008 & 2009 & 2008 & 2009 & 2008 & 2009 \\
\hline Control & $2.71 \mathrm{a}$ & $2.45 \mathrm{~b}$ & $22.30 \mathrm{a}$ & $19.48 \mathrm{~b}$ & $11.00 \mathrm{a}$ & $8.33 \mathrm{a}$ & $13.33 \mathrm{a}$ & $12.00 \mathrm{a}$ \\
\hline $\begin{array}{l}1 \mathrm{~m} \text { from } \\
\text { Hedgerow }\end{array}$ & $2.47 \mathrm{a}$ & $2.30 \mathrm{a}$ & $19.99 \mathrm{a}$ & $14.57 \mathrm{a}$ & $10.33 \mathrm{a}$ & $8.00 \mathrm{a}$ & $12.00 \mathrm{a}$ & $11.33 \mathrm{a}$ \\
\hline $\begin{array}{l}2 \mathrm{~m} \text { from } \\
\text { hedgerow }\end{array}$ & $2.48 \mathrm{a}$ & $2.43 \mathrm{ab}$ & $20.86 \mathrm{a}$ & $18.54 \mathrm{ab}$ & $11.67 \mathrm{a}$ & $9.00 \mathrm{a}$ & $13.67 \mathrm{a}$ & $12.67 \mathrm{a}$ \\
\hline S.E. & 0.78 & 0.03 & 1.18 & 1.24 & 0.66 & 0.38 & 0.88 & 0.47 \\
\hline LSD (0.05) & 3.09 & 0.15 & 4.63 & 4.90 & 2.61 & 7.12 & 3.46 & 1.85 \\
\hline
\end{tabular}

*Values with similar letter(s) within a column are not significantly different at $P=5 \%$ by Duncan's Multiple Range Test.

Effect of distance from Jatropha curcas hedgerow on yield and yield components of maize: The results indicate that yield and yield components were not affected by distance from hedgerow in the first year (Table 2 and 3 ). All yield component of 100 seed weight, number of rows/cob, number of seeds/row, weight of cob and weight of seed/con and yield were not significantly different $(P$ $<0.005$ ) in the first year. In the second year, only 100 seed weight, weight of cob, weight of seed/cob and 
yield were significantly different between the treatments. The highest yield (2.67 tons $\left.\mathrm{ha}^{-1}\right)$ of maize was obtained at the control (No hedgerow). This result did not differ from the $2 \mathrm{~m}$ distance from hedgerow where yield was 2.53 tons ha ${ }^{-1}$ (Table 3 ). 1 $\mathrm{m}$ distance gave the lowest value of $24.87 \mathrm{~g}, 205.7 \mathrm{~g}$, $100.2 \mathrm{~g}$ for 100 seed weight, weight of cob, weight of seed/cob (Table 2 and 3).

Table 2: Effect of distance from Jatropha curcas hedgerow on yield components of maize

\begin{tabular}{|l|c|c|c|c|c|c|}
\hline \multirow{2}{*}{ Treatments } & \multicolumn{2}{|c|}{100 seed weight (g) } & \multicolumn{2}{|c|}{ Number rows/cob } & \multicolumn{2}{c|}{ Number seed/row } \\
\cline { 2 - 6 } & 2008 & 2009 & 2008 & 2009 & $32.67 \mathrm{a}$ & $31.51 \mathrm{a}$ \\
\hline Control & $46.30 \mathrm{a}$ & $25.97 \mathrm{ab}$ & $14.17 \mathrm{a}$ & $14.60 \mathrm{a}$ & $32.89 \mathrm{a}$ \\
\hline $1 \mathrm{~m}$ from hedgerow & $39.00 \mathrm{a}$ & $24.87 \mathrm{a}$ & $15.00 \mathrm{a}$ & $14.00 \mathrm{a}$ & $28.89 \mathrm{a}$ & $31.78 \mathrm{a}$ \\
\hline $\begin{array}{l}2 \mathrm{~m} \text { from } \\
\text { hedgerow }\end{array}$ & $45.39 \mathrm{a}$ & $26.78 \mathrm{~b}$ & $15.58 \mathrm{a}$ & $14.45 \mathrm{a}$ & $30.67 \mathrm{a}$ \\
\hline S.E. & 2.93 & 0.63 & 0.58 & 0.15 & 1.70 & 1.87 \\
\hline LSD (0.05) & 11.51 & 1.49 & 2.29 & 0.62 & 6.70 & 5.57 \\
\hline
\end{tabular}

Table 3: Effect of distance from Jatropha curcas hedgerow on yield and yield components

\begin{tabular}{|c|c|c|c|c|c|c|c|c|}
\hline \multirow[t]{2}{*}{ Treatment } & \multicolumn{2}{|c|}{ Weight of cob (g) } & \multicolumn{2}{|c|}{ Weight of seed/cob (g) } & \multicolumn{2}{|c|}{ Stover weight (tons/ha) } & \multicolumn{2}{|c|}{ Grain Yield (tons/ha) } \\
\hline & 2008 & 2009 & 2008 & 2009 & 2008 & 2009 & 2008 & 2009 \\
\hline Control & $384.3 \mathrm{a}$ & $296.2 \mathrm{~b}$ & $204.6 \mathrm{a}$ & $121.9 \mathrm{~b}$ & $21.12 \mathrm{a}$ & $7.83 \mathrm{~b}$ & $2.99 \mathrm{a}$ & $2.67 \mathrm{~b}$ \\
\hline $\begin{array}{l}1 \mathrm{~m} \text { from } \\
\text { hedgerow }\end{array}$ & $262.8 \mathrm{a}$ & $205.7 \mathrm{a}$ & $159.2 \mathrm{a}$ & $100.2 \mathrm{a}$ & $14.15 \mathrm{a}$ & $5.42 \mathrm{a}$ & $2.50 \mathrm{a}$ & $1.98 \mathrm{a}$ \\
\hline $\begin{array}{l}2 \mathrm{~m} \text { from } \\
\text { hedgerow }\end{array}$ & $344.3 \mathrm{a}$ & $269.5 a b$ & $202.2 \mathrm{a}$ & $114.2 \mathrm{a} \mathrm{b}$ & $17.85 \mathrm{a}$ & $7.34 \mathrm{ab}$ & $2.84 \mathrm{a}$ & $2.53 \mathrm{ab}$ \\
\hline S.E. & 10.33 & 22.1 & 12.64 & 5.35 & 1.81 & 0.56 & 0.13 & 0.15 \\
\hline LSD (0.05) & 40.54 & 86.8 & 49.64 & 21.00 & 7.12 & 2.21 & 0.51 & 0.61 \\
\hline
\end{tabular}

*Values with similar letter(s) within a column are not significantly different at $P=5 \%$ by Duncan's Multiple Range Test.

\section{DISCUSSION}

Effect of distance from Jatropha curcas hedgerow on growth of Maize: Growth of maize was highest with increasing distance from the hedgerow of Jatropha curcas. In the first year, the no difference observed between the treatments presupposes that root extension and crown was not extensive enough to compete for resources with the test crop. Difference in the second year can be attributed to competition at closer spacing to the hedgerow. A number of findings support the hypothesis that reduced growth of maize closer to hedgerows could be as a result of competition for resources and shading in the second year. Newman et al. (1998) reported that where shading occurs in tree based intercropping system, a 'parabolic effect' on crop height and yield has been observed within the intercropping agricultural crop. The apex of the parabola (i.e. the greatest growth) occurs in the middle of the crop strip with growth reduced nearest the tree hedge. They also observed that leaf weight and internodes distance were also highest in the middle of the crop strip (Reynolds et al. 2007). Two crop species (corn and soy bean) and two tree crops (hybrid poplar and silver maple) were examined for their potential competitive interactions. Of the two crops, corn was the most detrimentally impacted by tree competition (Reynolds et al. 2007). Working with temperate tree-based intercropping systems in China, Wu and Zhu (1997) also observed that interrow spacing was significant factor influencing tree shading.

Effect of distance from Jatropha curcas hedgerow on yield of maize: Yield and yield 
parameters which include 100 seed weight, weight of cob and weight of seed per cob grain yield were significantly affected by distance from the hedgerow. Closer spacing from hedgerow $(1 \mathrm{~m})$ had the lowest yield and yield parameters. These results obtained can still be attributed to competition for resources at closer spacing since no reported difference was observed in the first year. Similar studies also report of decline in yield at closer spacing. Szott et al. (1991) found that yield generally increased with distance from hedges, suggesting that below-ground competition for water and nutrients reduce crops near the hedges. Planting in Indiana shown that under conditions of $1.5 \mathrm{~m}$ spacing within rows and $6.8 \mathrm{~m}$ between rows, increased yields on a per hectare basis early in the planting were observed due to an edge effect on corn rows planted adjacent to young trees (Goqerty, 1994). Newman et al. (1998) reported that corn yield and field beans yield were reduced by 63 and 68\% respectively, when intercropped with paulownias, a temperate tree species with desirable crown characteristics. To avoid these yield losses Simpson (1999) suggested that the canopies of trees be pruned to reduce shading and that the trees also be root - pruned to reduce possible competition effects for soil moisture.

\section{CONCLUSION}

Based on the results obtained it can be concluded that competition for resources with Jatropha curcas occurs at closer spacing. In order to reduce competition due to roots, a minimum distance of $2 \mathrm{~m}$ from hedgerow should be used. Within the first year of establishment of Jatropha curcas competition is likely not to occur. During this period planting closer to hedgerow could improve the yield of maize through increase plant density.

\section{REFERENCES}

Abalu, G. and Hassan R., (1999). Agricultural productivity and natural resources use in South Africa. Food Policy 23 (6): 477- 490.

Cameron, D.M., Gutteridge, R.C. and Rance, S.J. (1991). Sustaining multiple production systems. Forest and Fodder trees in multiple use systems in the tropics. Tropical Grasslands 25:165.

FAO, (2003). Forestry outlook study for Africa: Sub regional Report West Africa. Food and Agriculture Organization of limited Nations. Rome. Italy.

Goqerty, R. (1994). Companion crops for corn, the furrow 99 (5): $7-8$

Kang, B.T., Wilson, G.F. and Nangju, D. (1981a). Leucaena (Leucaena leucocephala. Lam.De wit.) pruning's as nitrogen source for maize (Zea mays L.) fertilizer Research 2 (4): 279.

Kang, B.T., Wilson, G.F. and Sipkens, L. (1981b). Alleycropping maize (Zea mays L.) and Leucaena (Leucaena leucocephala Lam.) in Southern Nigeria: Plant and Soil 63: 165.

Newman, S.M., K. Bennett, Y. Wu. (1998). Performance of Maize, Beans and Ginger as Intercrops in Paulownia Plantations in China. Agrofor. Syst. 39:23-30.

OCAR (Agricultural and Rural Development Department) (2002). Appraisal Report on Community Forestry Management Project. April, 2002.

Reynolds, P.E., J.A. Simpson, N.V. Thevathasan and A.M Gordon (2007). Effects of Tree Competition on Corn and Soybean Photosynthesis, Growth and Yield in a Temperate Tree-based Agroforestry Intercropping System in Southern Ontario, Canada, Ecological Engineering 29:362-371.

Scoones, I. (1998). Sustainable rural livelihoods: A framework for analysis. Working paper 72. Institute of Development Studies, Brighton, UK.

Shekhawat, Benniwal, Gour, V.K., Kumar, N. and Sharma N. (2009) Promoting Farming for the future. Jatropha World. CJP. weblinkIndia.NET.

Simpson, J. A. (1999) Effects of Shade on Corn and Soybean Productivity in a Tree Based Intercrop System In: Reynolds et al. (2007). Effect of Tree Competition on Corn and Soybean Photosynthesis, Growth and Yield in Temperate Tree-Based Agroforestry Intercropping System in Southern Ontario, Canada. Ecological Engineering 29: 362-371.

Szott, L.T., Palm, C.A. and Sanchez, P. A. (1991) Agroforestry in acid soils of the humid tropics. Advances in Agronomy 45: 275.

Twyman, C. (2001). Natural resource use and livelihoods in Botswana's wildlife management areas. Applied Geography 21: 45-68.

US Census Bureau (2002). World population: 1950 - 2050. US Census Bureau International Data base 10 - 2002.

Wilson, G.F. and Kang, B.T. (1981). Developing stable and productive biological cropping systems for the humid tropics. In Biological Husbandry-A scientific approach to organic farming. Edited by $B$. stonehouse. Butterworth, London.

World Bank (1994). Agricultural Sector Investment Program. World Bank Report. 1994.

Wu,Y. And Z. Zhu (1997) Temperate Agroforestry in China. In : Gordon A. M, Newman, S.M. (eds), Temperate Agroforestry Systems. CAB International Press, Wallingford, UK. Pp 149-179. 